\title{
The Role of Employer-Provided Sick Pay in Britain and Norway
}

\author{
Alex Bryson* and Harald Dale-Olsen** \\ $*$ UCL and IZA \\ **Institute for Social Research and IZA, Norway
}

August 2018

\begin{abstract}
Higher replacement rates often imply higher levels of absenteeism, yet even in generous welfare economies, employers provide sick pay in addition to the public sick pay. Using comparative population-representative workplace data for Britain and Norway we show that close to $50 \%$ of private sector employers in both countries provide sick pay in excess of statutory sick pay. However, the level of statutory sick pay is also much higher in Norway than in Britain. In both countries, private sick pay as well as other benefits provided by employers are chosen by employers in a way that- maximizes profits having accounted for different dimensions of labour costs. Several health-related privately provided benefits are often bundled. In both countries easy-to-train workers, high turnover and risky work are linked to less extensive employer provision of extended sick leave and sick pay in excess of statutory sick pay. In contrast, the presence of a trade union agreement is strongly correlated with both the provision of private sick pay and extended sick leave in Britain but not in Norway. We show that the sickness absence rate is much higher in Norway than in Britain. However, the higher level of absenteeism in Norway compared to Britain relates to the threshold for statutory sick pay in the Norwegian public sick pay legislation. When we take this difference into account, no significant difference remains.
\end{abstract}

Key-words: absenteeism, public sick pay, private sick pay, comparative

JEL-codes: H31, J22, J28, J32

Acknowledgement: We thank the Editors, two anonymous referees, the participants at the COPE2017-workshop in Zurich and at the IZA Workshop on Health and the Labor Market in Bonn 2017 for fruitful discussions and helpful suggestions. We thank the Norwegian Research Council for funding (grant No. 202647 and No. 227117) and the sponsors of the Workplace Employment Relations Survey 2011 (Department for Business Innovation and Skills, Acas, ESRC and NIESR) and Britain Data Archive for access to the WERS data. Corresponding author: Harald Dale-Olsen, hdo@socialresearch.no. 


\section{Introduction}

Sick pay constitutes insurance against income loss from not being able to work due to sickness or injury. It can also provide workers with incentives to take time off to stop the spread of illness (Skatun, 2003). However, absenteeism can be expensive when employers must absorb the cost of sick pay and when it disrupts the production of other workers. Moral hazard could exacerbate this problem when workers over-utilize sick days, particularly if sick pay is generous. On the other hand, too little sick pay can result in presenteeism, which occurs when sick workers show up at work (Goetzel et al., 2004; Hemp, 2004). Presenteeism causes contagion, which can also be costly. Thus, determining an optimal sick pay level can be difficult. In both Britain and Norway, public expenditures on sick pay are considerable. ${ }^{1}$ And yet, despite the concerns above, nearly half of private employers in Britain and Norway - two very different countries, as we shall see - chose to provide supplementary sick pay to workers absent due to illness. ${ }^{2}$ Why?

In this paper, we study how absenteeism relates to employer-provided sick pay and publicly provided sick pay, thus shedding light on how societies deal with the costs associated with absenteeism and presenteeism. The consensus is that economic incentives affect absenteeism. Analyses of reforms of the public sick pay legislation in several countries reveal that absenteeism and replacement rates are positively related (Johansson and Palme, 1996; Johansson and Palme, 2002; Henrekson and Persson, 2004; Ziebarth and Karlsson, 2010; Ziebarth, 2013; Csillag, 2017). Similarly, when public or private incentives increase the returns to worker absenteeism drop (Barmby et al., 1995; Brown et al., 1999; Dale-Olsen, 2012, 2013b). However, several studies identify heterogeneous effects across workers (Ziebarth, 2013; Ziebarth and Karlsson, 2013), with some worker groups unaffected by financial incentives. Such heterogeneous effects may result from offsetting private and public sick pay schemes. If statutory sick pay is set lower than what is privately optimal, employers might choose to provide additional contractual sick pay. Treble and

\footnotetext{
1 In Norway, for example, public sick pay constitutes $1.5 \%$ of GDP (The government budget, 2010). See (http://www.statsbudsjettet.dep.no/upload/Statsbudsjett_2010/dokumenter/pdf/summary_ national\%20_budget_2010.pdf). Even in Britain where the sick pay system is less generous, the direct cost of sick pay was $£ 11.6$ billion in 2003 (Barham and Begum, 2005). The European sickness absence insurance schemes are quite similar to temporary disability insurance in the United States. In 2005, California's temporary disability insurance benefits cost $\$ 4.2$ billion - slightly less than the amount spent on unemployment insurance (Ziebarth and Karlsson, 2010).

2 In a LRD-survey (Labour Research Department 2015) conducted in 2013 around 70 percent of employers reported offering sick pay compensation worth around half or full pay. In a 2017 report (https://www.eef.org.uk/resources-and-knowledge/research-and-intelligence/industry-reports/sick-paybenchmark) from the Electrical Engineering Federation close to 80 percent of their members report that they provided occupational sick pay on top of the statutory sick pay. In Norway information on sick pay in excess of statutory sick pay is extremely limited.
} 
Barmby (2011) discuss this issue in detail, noting potential heterogeneity in the returns to 'more generous' sick pay regimes across firms. ${ }^{3}$

Our contribution is two-fold. First, we establish the role played by the public sick pay compensation regime by comparing sickness absence in Britain and Norway, identifying effects using distinctive features in the Norwegian "kink" in compensation that occurs at a point in the earnings distribution. In this sense, our focus is similar to Böckerman et al. (2018) who identify a strong behavioural absence response from a kink in the Finnish sick pay legislation, implying an elasticity of the duration of sickness absence with respect to the replacement rate in the order of 1.4. ${ }^{4}$ However, we do not pursue a regression kink design, but compare the difference this kink makes in Norway to a scenario - Britain - where no such kink exists, using micro workplace data that also net out heterogeneity across workplaces.

Second, we investigate the factors associated with employer-provided supplementation to the public sick pay compensation system. Barmby et al. (2002) show that in many countries public sick pay legislation is supplemented by additional privately funded sick pay, as might occur if employers use such pay to attract and retain valuable workers. However, with few exceptions (Barmby, 2002; Dale-Olsen, 2013b), there is little empirical evidence regarding the interaction between public and private sick pay.

As discussed by Treble and Barmby (2011), firms provide non-pecuniary goods such as private sickness insurance (sick pay) and set wages to maximize profits and do so while taking into account several different dimensions of labour costs, with absence and presenteeism costs being just two of those dimensions. Training costs and turnover costs may be other relevant dimensions. In Section 2 we present a model highlighting these additional dimensions. Trade unions might also bargain for private sick insurance if this non-pecuniary good is highly valued by union members.

The motivation for comparing sick pay regimes in Norway and Britain is two-fold. First, they are polar opposites in terms of redistribution and welfare regimes, as characterised by typologies such as Esping-Andersen's (1990) (he differentiated between the U.S. and Sweden), creating potentially quite different incentives for firms to offer sick pay compensation, and for workers to take absence. Second, and relatedly, these countries are quite different when it comes to absence levels: Norway has among the highest absence rates in Europe, whereas Britain is among those with the lowest rates (OECD, 2010; Gimeno et al., 2004). Others who have conducted cross-

\footnotetext{
${ }^{3}$ The human capital health-model of Grossman (1972) ignores the moral hazard issue in absenteeism, but instead presents health as an investment object such as education. In a recent paper, Pichler and Ziebarth (2016) merge absenteeism and presenteeism modelling to present a unified strategy analysing sick leave behaviour.

${ }^{4}$ Following a reform of German statutory sick pay Ziebarth and Karlsson (2013) identify (based on SOEP data), that the elasticity of sickness absence with respect to the benefit level is around 0.9, a response which is somewhat weaker than that found by Böckerman et al. for Finland.
} 
country studies have suggested such differences relate to sick pay systems, rather than differences in employment protection legislation (Frick and Malo, 2008). Thus, if we establish similarities, this is actually strong evidence of a pervasive behaviour.

In the remainder of the paper: Section 2 describes the sick pay legislation in Britain and Norway. In Section 3 we present a simple model of shirking, training and turnover costs. The econometric strategy is described in Section 4. Data is described in Section 5. Our empirical findings are presented in Section 6, while Section 7 concludes.

\section{The sick pay legislation and private supplementary sick pay}

The British public sick pay legislation (Statutory Sick Pay (SSP)) is relatively simple: each worker receives $f^{81.60}$ per week for 28 weeks for sickness absence (2011 figures), a figure equivalent to around 13.5 hours per week at the adult minimum wage. The first three days of sick leave are "qualifying days" with no pay. Norwegian public sick pay, on the other hand, provides from day 1 for up to one year's full compensation up to what is defined as $6 \mathrm{G}$, where $\mathrm{G}$ is the baseline figure in the Social Service benefit system ( $1 \mathrm{G}$ is equivalent to $£ 8638) .{ }^{5}$ For pay above this threshold, only 6G is paid in public sick pay. As such the Norwegian sick pay legislation is comparable to the Finnish system: both are kinked (the Finns have more than one kink) (Böckerman et al., 2018). Figure 1 highlights the difference between British and Norwegian public sick pay.

\section{FIGURE 1 AROUND HERE ]}

Both in Britain and Norway employers are free to top-up publicly provided sick pay compensation. In $2003,40 \%$ of Norwegian private sector workplaces offered additional compensation for those above the threshold (Dale-Olsen, 2012). The employer-provision of top-up sick pay compensation is seen in other countries as well (Barmby et al., 2002). In Britain and Norway workers usually need a physician to certify illness after a designated number of sick leave days. In Britain, this occurs after 7 days. In Norway it is usually after 3 consecutive absence days. In Norway employees are limited to four self-declared spells per annum after which all absences (regardless of longevity) have to be physician-certified. A minority of firms allow longer and more periods.

During the period under study British SSP was paid by the employers, but due to a Percentage Threshold Scheme (PTS) employers could recover SSP costs for their employees' sick leave if the total SSP paid in a tax month exceeded 13 percent of the employer's (Class 1) National Insurance contribution in the same month. In 2014 the PTS was replaced with programs aimed at

\footnotetext{
${ }^{5}$ All money values in the paper are based on 2011 pounds (PPP-adjusted), where $1 f=9.032$ Norwegian krones $(\mathrm{NOK}))$.
} 
individuals and not employers, including Fit to Work, an occupational health advisory service, which aims to provide advice for managing absence and improve return-to-work rates, but does not provide financial support. In Norway, the first 16 days of the absence spell are covered or paid by the employer. The remaining spell is covered by the public authorities up to the $6 \mathrm{G}$-threshold.

\section{A simple model of shirking, training and turnover costs}

Workers mainly take sick leave due to illness, but there is a rich literature focussing on the shirking aspect of absenteeism. In this literature, there is a margin at which employees can choose whether to take sick leave or not, depending on the costs and benefits of doing so. ${ }^{6}$ At this margin sick leave can be interpreted as a reduction in worker effort.

By choosing a sick leave level, $a$, when facing imperfect monitoring, $\mathrm{N}$ identical workers maximise expected utility. Let the monitoring probability be $0<\mathrm{m}<1$. Since our focus is privately supplied sick pay, we simplify and assume that all firms monitor at the same level and costs. Monitoring intensity is usually treated as a key firm choice variable. Similarly, since our focus is privately supplied sick pay, statutory public sick pay is also ignored for simplicity.

Sick level $a$ can also be interpreted as the sick leave probability. By staying home on sick leave the worker receives sick pay S. By showing up to work a worker undertakes the contracted effort. As is common in "shirking"-models, work effort is assumed to be associated with disutility, that is, one can derive a cost of effort function, $\mathrm{C}$, expressed as a function of the presence probability (1-a). As is standard in the literature, we assume that $C$ is a convex function, that is, $C^{\prime}(1-a)>0$ and $\left.C^{\prime}(1-a)^{\prime}>0\right)$. An absent and monitored worker is fired. Each worker then maximises:

$$
(1-a) U(W)+a(1-m) U(S)+a m U(R)-C(1-a),
$$

where U expresses a Von Neumann-Morgenstern utility function, $U^{\prime}>0, U^{\prime \prime}<0, R$ expresses the worker's outside options. Workers' first order condition for maximization is given by:

$$
\text { 2) } \quad \mathrm{U}(\mathrm{W})-\mathrm{U}(\mathrm{S})+\mathrm{m}[\mathrm{U}(\mathrm{S})-\mathrm{U}(\mathrm{R})]=\mathrm{C}^{\prime}\left(1-\mathrm{a}^{*}\right) \text {, }
$$

such that the marginal cost of providing effort equals the marginal gain from showing up at work plus the added marginal loss if caught shirking.

This simple model then yields different predictions for Britain and Norway on absenteeism. Assume that the cost of providing effort can be represented by a quadric function, $C(1-a)=c(1-a)^{2}$. The sick pay in Britain could be interpreted as being equal to the outside option, i.e, $\mathrm{S}=\mathrm{R}$. For Norway, $S=W$ for wage levels below $6 \mathrm{G}$, but fixed at $S=6 \mathrm{G}$ above.

\footnotetext{
${ }^{6}$ For example, as Barmby et al. (1994) model this, each worker's health can be characterized by a continuous health index. Above a certain level, the worker will never be absent, and similarly, below a certain level the worker will always be absent. The thresholds, however, depend on the costs and benefits of absence, such as sick pay, monitoring probability, unemployment benefits etc. and even individual preferences.
} 
Thus $(1-\mathrm{a})^{\text {BRITAIN }}=[\mathrm{U}(\mathrm{W})-\mathrm{U}(\mathrm{R})] / 2 \mathrm{c}$, implying that $\frac{\partial a^{U K}}{\partial W}=-\mathrm{U}^{\prime}(\mathrm{W}) / 2 \mathrm{c}<0 . \quad$ For Norway and $\mathrm{W}<6 \mathrm{G}$ then $(1-\mathrm{a})^{\mathrm{Norway}}=\mathrm{m}[\mathrm{U}(\mathrm{W})-\mathrm{U}(\mathrm{R})] / 2 \mathrm{c}$, implying that $\frac{\partial a^{\text {Norway }}}{\partial W}=-\mathrm{mU}^{\prime}(\mathrm{W}) / 2 \mathrm{c}<0$. If monitoring of workers in Norway is very low or absent, then absence will not diminish with wages for wages less than $6 \mathrm{G} .^{7}$ Above $6 \mathrm{G}, \frac{\partial a^{\text {Norway }}}{\partial W}$ becomes equal to Britain, $\frac{\partial a^{\text {Norway }}}{\partial W}=-\mathrm{U}^{\prime}(\mathrm{W}) / 2 \mathrm{c}<0$. Thus, whereas in Britain, absenteeism should be negatively associated with wages across the wage distribution, in Norway, there should be little relationship between wages and absenteeism until wages hit the $6 \mathrm{G}$ threshold, whereupon a negative relationship should emerge.

The utility set up above could be interpreted as the utility of a worker staying at the firm, $\mathrm{U}^{\text {stay }}=\mathrm{U}$. Then worker mobility could be modelled as: $\mathrm{q}=\mathrm{q}(\mathrm{W}, \mathrm{S})=\operatorname{Pr}(\mathrm{U}$ (wage offer competing firm $\left.)>\mathrm{U}^{\text {stay }}\right)$. We easily see that $\frac{\partial U^{\text {stay }}}{\partial W}>0$ and $\frac{\partial U^{\text {stay }}}{\partial S}>0^{8}$, i.e., since $\mathrm{q}(\mathrm{w}, \mathrm{a})$, then $\frac{\partial q}{\partial W}<0$ and $\frac{\partial q}{\partial S}<0$.

In this modelling framework firms maximize profits by choosing the optimum mix of wages and sick pay (since all firms monitor at the same intensity and cost, monitoring costs can be ignored). Firm profits may be described by Equation 3), where workforce size is normalised to 1:

3) $\quad \Pi=(1-q)[(1-a) P-(1-a) W-(1-m) a S-Z(m)-T(q)]-q T(q)$,

where $\mathrm{P}$ expresses the value of the final product (product priceXquantum produced), $\mathrm{W}$ and $\mathrm{S}$ denote the wage and sick pay, respectively, a and $m$ express the absence rate and the monitoringand-found-shirking intensity $(0<\mathrm{m}<1)$, respectively. $Z$ expresses the cost of monitoring, where $Z^{\prime}>0$ and $Z$ " $>0$. Finally, we have entered a turnover (training) cost element, T, where T'> and T">0, in line with Salop (1979). The firm maximizes $\Pi$ w.r.t. W and S. This yields two first-order conditions (FOCs):

$$
\begin{gathered}
-\left\{[(1-\mathrm{a}) \mathrm{P}-(1-\mathrm{a}) \mathrm{W}-(1-\mathrm{m}) \mathrm{aS}-\mathrm{Z}(\mathrm{m})-\mathrm{T}(\mathrm{q})]+\mathrm{T}(\mathrm{q})+\mathrm{T}^{\prime}(\mathrm{q})\right\} \frac{\partial q}{\partial S}= \\
(1-\mathrm{q})\left[(1-\mathrm{m}) \mathrm{a}+(\mathrm{P}-\mathrm{W}-(1-\mathrm{m}) \mathrm{S}) \frac{\partial a}{\partial S}\right.
\end{gathered}
$$

$$
\begin{gathered}
-\left\{[(1-\mathrm{a}) \mathrm{P}-(1-\mathrm{a}) \mathrm{W}-(1-\mathrm{m}) \mathrm{aS}-\mathrm{Z}(\mathrm{m})-\mathrm{T}(\mathrm{q})]+\mathrm{T}(\mathrm{q})+\mathrm{T}^{\prime}(\mathrm{q})\right\} \frac{\partial q}{\partial W}= \\
-(1-\mathrm{q})\left[(1-\mathrm{a})+(\mathrm{P}-\mathrm{W}-(1-\mathrm{m}) \mathrm{S}) \frac{\partial a}{\partial W}\right.
\end{gathered}
$$

\footnotetext{
${ }^{7}$ Note that we focus on physician-certified sick leaves. It might be close to impossible to define such an absence as shirking. In addition, as in the other Scandinavian countries, Norwegian physicians seldom deny sickness certificates (Wahlström and Alexanderson, 2004; Carlsen and Nyborg, 2009).

${ }^{8}$ This is easily seen differentiating $\mathrm{U}^{\text {stay: }}: \frac{\partial U^{\text {stay }}}{\partial W}=(1-a) U^{\prime}(W)-[U(W)-(1-m) U(S)-m U(R)] \frac{\partial a}{\partial W}>0$ and $\frac{\partial U^{\text {stay }}}{\partial S}=a(1-m) U^{\prime}(S)-\left[U(W)-(1-m) U(S)-m U(R)-C^{\prime}(1-a)\right] \frac{\partial a}{\partial S}>0$ (note that the last term in bracket is 0 since it is the FOC).
} 
The first FOC says that the marginal turnover costs saved by increasing sick pay should be equal to the marginal shirking costs. This shows that firms might rationally increase (or introduce) private sick pay even if it increases absenteeism, if the gains in turnover costs compensate for this. The second FOC says that the marginal wage costs (and thus profit) should be equal to the saved marginal turnover and absence costs.

Finally, note that in the model we have highlighted the use of employer-provided sick pay as a device for the employer to maximise profits while taking into account costly turnover. One can easily extend this approach to employers' provision of bundles of benefits. More complex modelling of wages, non-wage benefits and worker turnover is found in Gronberg and Reed (1994) and Hwang, Mortensen and Reed (1998). ${ }^{9}$

\section{Empirical Strategy}

Using the framework outlined in Section Three we address two related questions: which firms provide sick pay above the statutory limit, and how is absenteeism affected by sick pay regimes?

First, to study how the employer provision of sick pay is related to training costs, other work organization measures, non-wage benefits, work characteristics and unions, we present Spearman bivariate correlations, then apply simple linear probability models and linear regressions to study how these workplace conditions vary between countries and across the levels of statutory sick pay. By doing this, we map out the similarities and differences between Britain and Norway in the employer provision of sick pay.

Second, to identify the role played by public sick pay provision we exploit differences in public sick pay provision across Norway and Britain. As described in Section 2 the Norwegian public sick pay system is kinked: full compensation occurs until the earnings threshold of $6 \mathrm{G}$, at which point sick pay is capped, regardless of additional earnings. Since no such kink exists in Britain, the empirical strategy of directly comparing the relationship between absenteeism and pay between Norway and Britain under and above the Norwegian threshold should provide insight into how sick pay affects absenteeism.

Let $a$ denote the workplace sick leave rate. The sick leave rate is highly non-normally distributed, thus we use the logit-transform to normalise our dependent variable (i.e., $\ln [a /(1-a)])$. Then we apply simple difference-in-difference OLS regressions of this transformed workplace

\footnotetext{
${ }^{9}$ Dale-Olsen (2006) apply the Hwang, Mortensen and Reed-framework to an analysis of worker turnover, pay and sickness absence.
} 
sickness rate on the workplace average of log hourly wages and interactions with a country dummy and a dummy for pay above the threshold and other controls.

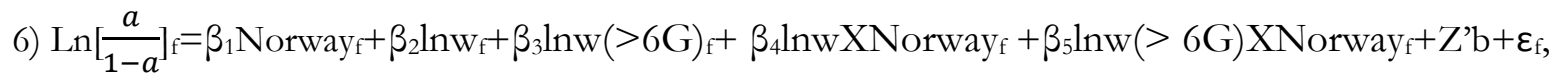
where $Z$ 'b is a vector of controls (which we vary in sensitivity tests), and $\varepsilon$ expresses a standard error term. Note that due to the logit transformation, to derive the average elasticity of absence rate w.r.t. wages in these regressions, one has to multiply the estimated variable by the average of $(1-a)$.

Note also that our approach does not identify causal relationships, and we cannot completely take into account non-random selection of workers (with respect to health or shirking behaviour) to workplaces with different average wages. However, as shown in Dale-Olsen (2013a) it is difficult for Norwegian workers to sort differently just above and below the 6G-threshold. Our analysis compares the country-differences in relationship between sick leave and pay above and below this threshold.

First, we expect Britain to experience lower sick leave rates than Norway, at least partly because of the less generous sick pay legislation (and thus in accordance with Frick and Malo (2008) and those studies revealing a positive relationship between absence rates and replacement rates). Second, we expect to see little wages-absence relationship in Norway under the 6G-threshold relative to the impact observed in Britain, but for workers earning above the 6G-limit behaviour should be similar in the two countries since the replacement rate falls for Norwegian workers above this threshold. In Norway we should see absenteeism becomes more negatively relative to wages compared to those workers earning under the 6G-threshold. Our analyses take into account employer-provided sick pay, other benefits and pay systems.

\section{Data}

Our data are the British ${ }^{10}$ Workplace Employment Relations Survey 2011 (WERS 2011) and the Norwegian Workplace Employment Relations Survey 2012 (NWERS 2012) supplemented by Norwegian population-wide register data (for the period 2000-2012). Although WERS (NWERS) covers workplaces with at least 5(10) employees in all sectors of the British (Norwegian) economy, we confine our analyses to the private sector workplaces with at least 10 employees where the market setting means the profit-maximising assumptions invoked earlier are most likely to hold.

\footnotetext{
10 Throughout we have referred to Britain. The data are British, covering England, Scotland and Wales, but not Northern Ireland (which is part of the UK but not Britain).
} 
Information in WERS was acquired through face-to-face interviews, which were conducted with the manager at the workplace responsible for employment relations. The response rate in 2011 was 46\%. Information in NWERS was acquired through computer-assisted telephone interviews, which were conducted with the daily manager at the workplace or the manager responsible for employment relations. The response rate was $54 \%$, but since the main reason for non-response was respondents not being reached by Statistics Norway (36 percentage points) and not by respondents refusing to participate, selection issues are unlikely to be a problem. ${ }^{11}$ WERS is documented in van Wanrooy et al. (2013), while NWERS is documented in Holmøy (2013).

The British WERS survey comprises information on absenteeism at the workplace level, while wage information is available at the worker level (and aggregated to the workplace). Absenteeism is measured as the absence rate at the workplace based on the last 12 months that workers were absent due to illness and other non-authorised reasons. ${ }^{12}$ Thus the absence measure comprises physician- and self-certified absences. In addition, WERS contains information on a range of organisational practices, risks, injuries, additional sick pay and pay systems. The Norwegian WERS comprises similar data on organisational issues, pay systems, risk and self-certified absence rates. ${ }^{13}$ Wages and physician-certified absence days are collected from administrative registers of the Norwegian Tax Authorities and the Norwegian Labour and Welfare Service, which comprise the complete population of Norwegian jobs, workers, workplaces and firms. Based on the public administrative records, we can measure the workplace-level physician-certified absence rate based on the total number of sick leave days during the last 12 months that workers were absent due to physician-certified illness. By combining NWERS-information on self-certified absence rates with physician-certified absence rates based on the administrative records, we get an absence rate measure comparable to Britain WERS measure: the total workplace absence rate.

Note that physician-certified sick spells in Norway might be partial in the sense that a worker may be 'signed off' sick for part of the time. We take this into account by creating two measures; one measure based on the observed absence days, and one measure where we weight the absence days by how partial the absence is. For example, 1 day on 100 percent sick leave is equal to 2 days on 50 percent sick leave.

\footnotetext{
${ }^{11}$ In NWERS 12.7 percent of the issued sample refused to participate. In both NWERS and WERS detectable response biases were corrected using sampling weights.

12 The question reads: "Over the last 12 months what percentage of work days was lost through employee sickness or absence at this workplace? Exclude authorised leave of absence, employees away on secondment or courses or days lost through industrial action."

13 The question reads: "Over the last 12 months what percentage of work days was lost through self-certified sickness absence at this workplace?"
} 
We pool the Norwegian and British workplace level data, and create an absence measure transformed to normality, the logit of the sick leave rate, in accordance with standard practice in the previous literature on absenteeism (Heywood and Jirjahn, 2004).

All money values in the comparative analyses are 2011 pounds (PPP-adjusted) $(1 £=9.032$ Norwegian krones (NOK)). Our key wage measure is the workplace-average of workers' log hourly wages.

Other key control variables are defined as follows:

6G-earnings threshold: a dummy taking the value of 1 whenever mean workplace earnings are above 6G.

Private supplementary sick pay: a dummy taking the value of 1 if sick pay in excess of statutory sick pay is provided.

Extended sick leave: a dummy taking the value of 1 if extended sick leave arrangements are provided by the employer.

Private health insurance: a dummy taking the value of 1 if private health insurance is provided.

Risky work: a dummy taking the value of 1 if employer responds that the worker faces very high or high levels of risk at work, while taking the value of 0 if workers face little or no risk.

Trade union agreement: a dummy taking the value of 1 if at least one trade union agreement is established.

Quick training time: a dummy taking the value of 1 if the training time making fresh recruits equally productive as experienced worker is less than a month, zero otherwise ${ }^{14}$.

High turnover: a dummy taking the value of 1 if workplace worker turnover is above the median in the sample.

In addition to these key control variables, we incorporate an industry dummy vector based on 2-digit codes, and a workforce control vector comprising the log number of employees, the ratio of full-time to part-time workers, and 8 country-specific dummies capturing differences in occupational composition (basically 1-digit ISCO occupational codes, with management and professionals as reference).

\section{Results}

\subsection{Descriptive aggregate evidence}

\footnotetext{
${ }^{14}$ Quick training time is defined using the question "About how long does it normally take before new recruitments in the main occupational group are able to do their job as well as more experienced employees already working here?". Answers of less than one month are coded 1 , otherwise they are coded 0 .
} 
We start by looking at aggregate statistics. In Table 1 we present figures for private sector workplaces with more than 10 employees in the Great Britain and Norway. The first and obvious finding is that the sick leave rate is considerably higher in Norway (nearly 7 percent) than in Great Britain (around 4 percent)

[ TABLE 1 AROUND HERE ]
[ FIGURE 2 AROUND HERE ]

Employer-provided sick pay is equally prevalent in Norway as in Britain (around 48\% in both countries) but distributed quite differently as expected due to the kink in the Norwegian sick pay scheme. High wage workplaces (defined as workplaces with an average wage above 6G $(£, 52,110)$, comprise $30 \%$ and $37 \%$ of the workplaces in Norway and Britain, respectively. Close to 45 percent of the Norwegian workplaces providing additional private sick pay have mean earnings above 6G, while less than 20 percent of the Norwegian workplaces with public sick pay only have mean earnings above 6G. In Britain, the percentages of workplaces having mean earnings above the 6G-threshold are approximately equal (36\% vs. 39\%). This is the first indication that the Norwegian kink in public provision influences the provision of private or contractual sick pay. In Britain this kink does not exist.

Employer-provided supplementary sick pay is only relevant for the minority of Norwegian workers employed by those employers who provide supplementary sick pay (those workers earning above $6 G)^{15}$, but it is potentially relevant for all British workers employed at similar workplaces since statutory sick pay is so low in Britain.

It is also evident from Table 1 that the non-wage benefits such as supplementary sick pay are bundled together with other health-related non-wage benefits such as extended sick leave and to a certain degree, the provision of private health insurance. Seventy-two percent of British employers providing private sick pay also provide extended sick leave, while only roughly 26 percent of those having only public sick pay provide extended leave. We see a similar pattern in Norway, although it is not so pronounced. Although much weaker, we also see that in both countries employers providing private sick pay are more likely to provide health insurance/General Physician-agremeent than those relying on public sick pay only.

Three other aspects in Table 1 are worth considering. First, both in Britain and Norway, employers are less likely to offer sick pay above the statutory minimum where it takes less time for

\footnotetext{
${ }^{15}$ Based on the Norwegian individual wage data comprising the whole population of workers for 2011, we see that the 6G-threshold in 2011 constitutes roughly the $68^{\text {th }}$ percentile in the wage distribution.
} 
new workers to be trained in their jobs. Quick training is more likely to occur under public sick pay only relative to additional private sick pay (50 and 70 percent more likely in Britain and Norway, respectively). This indicates that training costs could be important for the provision of sick pay in excess of the statutory minimum. Second, when worker turnover is high employers are less likely to provide private sick pay. Third, sick pay in excess of the statutory minimum is positively associated with trade union coverage in Britain but not in Norway (penultimate row in the table). Since sick pay in excess of the statutory minimum is a benefit important for most workers in Britain, but only high-wage workers in Norway, this is more important for unions in Britain than Norway (high wage workers are less unionised in both countries).

\subsection{Employer-provided sick pay in addition to statutory sick pay and other benefits and characteristics. Cross- country differences and similarities.}

Next, we consider the relationship between the provision of sick pay in excess of statutory sick pay and other workplace characteristics. We start by mapping out the country-differences regarding sick pay in excess of statutory sick pay, private health insurance, extended sick leave arrangements, risky work, trade union agreements, quick training ${ }^{16}$ and high turnover (above median in sample). We do this by estimating several linear probability models and linear regressions related to the provision or existence of these characteristics (by dummies or indexes). Each column of Table 2 presents our results related to these characteristics. We estimate two sets of models (no controls (Panel A) and one with 2-digit industry controls (Panel B), for both countries. The reference, as expressed by the intercept, in the regressions is Britain and earnings equal or less than 6G. Figure 3 pictures the marginal effects for three selected outcomes - supplementary sick pay, trade union agreements, and short training times.

\section{TABLE 2 AROUND HERE ]}

Employer-provided benefits such as health insurance, extended sick leave (self-declared) and sick pay in excess of statutory sick pay, and high-powered incentive schemes are more prevalent among high wage workplaces in both countries. The provision of supplementary sick pay does not differ between Norway and Britain for low-wage workplaces.

\section{[ FIGURE 3 AROUND HERE ]}

Sick pay in excess of statutory sick pay is particularly common in Norwegian high wage workplaces. This is no surprise, since the workforces in these workplaces are more likely to be

\footnotetext{
${ }^{16}$ If respondents reply "less than one month" to the question "About how long does it normally take before new recruitments in the main occupational group are able to do their job as well as more experienced employees already working here?” we define this as quick training.
} 
affected by the public sick pay threshold. Sick pay above the statutory minimum and these other health related benefits are akin to fringe benefits.

Figure 3, however, reveals two other important country differences and similarities. First, the earnings threshold matters little for union density in Britain. This is as expected. While union density might be related to wages (if higher union density reflects higher union bargaining power thus yielding higher wages), there is no reason to expect that this should be related to the Norwegian 6G-threshold. In Norway, we see that unionisation is much more common, but union density is lower above the threshold than below. Second, in both countries, high wage firms (those with earnings above the threshold) are less likely to report short training times. This is natural, to train workers for a longer duration, implies that these workers are more costly for their employer, but at the same time they will be more productive, and thus receive higher wages.

In Panel B) of Table 2, when we control for 2-digit industry differences, we see that some of the country differences and the differences between high wage and low wage workplaces relate to industry variation, and are thus hard to differentiate from other industry characteristics. Even so, privately provided sick pay in excess of statutory sick pay is more prevalent among Norwegian high wage workplaces, even within-industry. This is a natural consequence of the 6G-threshold in the Norwegian public sick pay. This is also seen in Figure 4, where we present the predicted probabilities associated with 6 selected outcomes. High wage-workplaces in Norway are more likely to provide supplementary sick pay, extended sick leave and private health insurance, but less likely to undertake short-training time and to experience high worker turnover, than low wage workplaces. They are even less unionised, but still at a high level.

\section{FIGURE 4 AROUND HERE}

At same time, the similarities between the countries along these dimensions are perhaps surprising, as indicated in Table 3. When estimating bivariate Spearman correlations separately for each country, we find that health related privately provided benefits are correlated in both countries. Similarly, in both countries easy-to-train workers (quick-training), high turnover and risky work are linked to less extensive employer provision of extended sick leave and sick pay in excess of statutory sick pay.

\section{[ TABLE 3 AROUND HERE ]}

On the other hand, differences are also striking. For example, we see that the presence of a trade union agreement is strongly correlated with both the provision of private sick pay and extended sick leave in Britain but not in Norway. In Norway, the correlations between unionisation and extended sick leave is actually negative. This indicates that in a country with a generous welfare 
system such as Norway, health-related benefits are less important for unions when bargaining locally with employers. ${ }^{17}$

\subsection{The impact of the Norwegian sick pay threshold}

Next, we turn to the OLS regression analyses of how pay (and thus indirectly sick pay) affect sickness absence. In Table 4 we report the results from several linear regressions of logit of the sick leave rate on a dummy for Norway, log hourly wages, a dummy for wages above the Norwegian 6G-sick pay threshold, interaction terms, and controls with respect to industry, pay schemes (performance and merit pay, employee share scheme (ESS) and Company Share Ownership Programs (CSOPs), and work organisation (e.g., teams). In Panel A) we present the parameter estimates, while Panel B) presents the estimated linear expressions (of the interactions). In Models 0, 1 and Model 5 we add no controls. In models 2, 4, and 6 we add our key control vector, while in Model 3 we even add a workforce control vector. ${ }^{18}$ Model 5 and Model 6 estimate the adjusted sick leave rate for Norway to take account of partial sick leave. Finally, in Model 4 and Model 6 we focus on workplaces where employers do not provide supplementary sick pay.

We know from our theoretical predictions in the Section 3 and as seen in Figure 2 that the sick leave level is higher in Norway than in Great Britain. This is confirmed by the result of Model 0 in Panel A). However, we see from the remaining models of Table 4 that when we take into account wages (and thus implicitly sick pay), then Norway is no different to Britain. However, we see that the 6G-threshold matters for sick leave in Norway, but not in Britain. Sick leave in Britain does not differ significantly below and above the Norwegian 6G-threshold, which is as expected since this threshold does not exist in Britain.

\section{TABLE 4 AROUND HERE ]}

These regressions indicate that the replacement rate matters for Norwegian workers' sick leave behaviour. Our robustness check based on the adjusted sick leave rate reinforces this picture. The regressions also reveal that when focussing on employers not providing sick pay in excess of statutory sick pay, the negative relationship between pay and sick leave becomes stronger (Models 4 and 6) than for all employers (the other models). This implies that the relationship between pay

\footnotetext{
${ }_{17}$ One potential reason for this might be the difficulties unions face when bargaining for terms and conditions that are in excess of already fairly generous statutory provision.

${ }^{18}$ Note that in our theoretical model workforce turnover, absence rates and wages are endogenously determined. From the equilibrium search literature we know that worker turnover, workforce size and wages are endogenously determined (e.g., Hwang et al., 1998): in equilibrium workforce size equals the inverse of the quit rate). Similarly, working hours composition, occupational composition and pay structure are also determined by employers. Thus both models 2 and 3 are primarily added as robustness checks, and not for causal evidence.
} 
and sick leave is much weaker when private sick pay is provided, i.e., when sick leave to a lesser extent implies an income loss.

In Panel B) we estimate the linear expressions (of the interactions). We see that wages are less negatively related to the logit of the sick leave rate in Norway than in Britain. However, we also note that with one exception, wages for the Norwegian $<6 \mathrm{G}$-workplace are not significantly related to the sick leave rate. By multiplying the linear expressions in Panel B) by (1-a), where a denotes the workplace sick leave rate, one can derive the estimated elasticity of sickness leave rate with respect to wages for the different models. In Table 5 we report these elasticities based on the estimates from Table 4 Model $2 .{ }^{19}$ We calculate the elasticities for two values of the workplace sick leave rate: at country mean (for all workplaces, regardless of wage level) and at the country-specific means for workplaces with earnings above the 6G-threshold and for those with earnings below the threshold.

\section{TABLE 5 AROUND HERE ]}

The elasticity of sick leave with respect to wages is strongly negative in Britain, but we know from Table 4 that it does not differ significantly below and above the Norwegian 6G-threshold. Overall in Britain we find elasticities from -0.61 to -0.48 . For Norway, however, no significant relationship between sick leave and wages is found below the $6 \mathrm{G}$-threshold. A strong negative elasticity of -0.25 appears for the Norwegian high wage workplaces. If the relative difference in the elasticity between those below $6 \mathrm{G}$ and those above $6 \mathrm{G}$ had been similar to what we see in Britain, our non-significant estimate would have been around -0.13 . This indicates that the cut in the Norwegian replacement rate affecting those with earnings above $6 \mathrm{G}$ causes the elasticity nearly to double. However, the Norwegian elasticity is still clearly much lower than the one estimated for Britain. Several explanations are possible. First, if benefit bundles and working conditions affecting sick leaves are more strongly related to wages in Britain than in Norway, we would observe the relationship between wages and sick leaves to become stronger in Britain. Alternatively, a stronger sorting with respect to wages and sick leave may occur in Britain than in Norway.

\section{Conclusion}

In this paper, we have studied the provision of private sick pay in excess of statutory sick pay in Great Britain and Norway, two very different welfare regimes. In contrast to the majority of

\footnotetext{
${ }^{19}$ Note in models 1-6, when we allow the relationship between wages and absenteeism to be kinked (at 6G), we do not allow a jump at the kink (thus following a KRD-approach). Incorporating such a jump, would not have qualitatively have changed our results.
} 
Norwegian workers who face a 100 percent replacement rate when absent from work due to illness, British workers receive statutory sick pay on a par with the minimum wage. However, due to a 6Gthreshold for sick pay in Norway, not all Norwegians face a 100 percent replacement rate. We utilize this difference and show that the threshold and pay and thus indirectly sick pay are crucial for explaining the higher sick leave rate in Norway compared to Britain. Conditional on the threshold and pay absenteeism is actually similar in the two countries, but absenteeism is much more sensitive to pay in Britain than in Norway even when we focus on employees in workplaces with no provision of sick pay in excess of statutory sick pay. The important observation is that when pay is no longer fully compensated, the sick leave rate drops.

Given the generous Norwegian public sick pay it is no big surprise that private sick pay in excess of statutory sick pay is less prevalent in Norway than in Britain, and Norwegian employers primarily provide for high-wage workforces. However, in both these countries the provision of excess sick pay is clearly part of the health-related benefits package provided by employers, and employers provide this when recruitment costs are high and the working conditions are beneficial to workers. Bad working conditions often cause injuries and sick leave, and thus private sick pay becomes more expensive for employers. Firms provide non-pecuniary goods such as private sick insurance (sick pay) and set wages to maximize profits while taking into account several different dimensions of labour costs, absence costs being just one dimension. Training costs and turnover costs are other relevant dimensions. In addition, trade union agreements in Britain raise the probability of sick pay in excess of statutory sick pay.

For policymakers our paper provides two important lessons. First, the way in which statutory sick pay compensation is designed matters for absenteeism. Second, firms might provide additional benefits to worker groups if by doing so they profit, thus if replacement rates are cut, worker groups with good outside options or a strong bargaining position could be less affected by the reduction in replacement rates. Thus, when reforming public sick pay legislation, policymakers should take care so that such reforms do not cause unwanted inequality and unexpectedly affect the level of living of vulnerable worker groups. If these groups are weaker or less attractive in the labour market (i.e., with inferior outside options) and one acknowledges that the sick leave rate of these groups is driven largely by illness, cutting public sick pay will increase inequality, since attractive worker groups will receive employer-provided sick pay and thus face less income loss when ill. 


\section{Appendix}

Tables

\section{[ TABLE A1 AROUND HERE ]}

\section{References}

Barham, C. and N, Begum (2005), "Sickness absence from work in the UK"e Labour Market Trends, Office for National Statistics, April: 149-158.

Barmby, T.A., Sessions, J. and Treble, J. G. (1994), “Absenteeism, Efficiency Wages and Shirking," Scandinavian Journal of Economics, 96, 561 - 566.

Barmby, T.A., Orme, C., and Treble, J. (1995), “Worker Absence Histories: A Panel Data Study”, Labour Economics, Vol. 2(1), pp. $53-65$.

Barmby, T.A., Ercolani, M. G. and Treble, J. G. (2002), "Sickness Absence: An International Comparison”, Economic Journal, 112, F315 - F331.

Brown, S., Fakhfakh, F. and Sessions, J.G. (1999), “Absenteeism and Employee Sharing: An Empirical Analysis based in French Panel Data, 1981 - 1991”, Industrial and Labor Relation Review, 52, 234 -251 .

Böckerman, P. O. Kanninen and I. Suoniemi (2018), “A Kink that Makes You Sick: the Incentive Effect of Sick Pay on Absence in a Social Insurance System". Journal of Applied Econometrics, 33, 568 - 579.

Carlsen, B. and Nyborg, K. (2009), "The Gate is Open: Primary Care Physicians as Social Security Gatekeepers", memo 7/2009, Department of Economics, University of Oslo.

Csillag, M. (2017), The incentive Effects of Sickness Absence Compensation - Analysis of a "Natural Experiment" in Eastern Europe," mimeo., Budapest Institute for Policy Analysis.

Dale-Olsen, H. (2006). "Estimating Workers' Marginal Willingness to Pay for Safety Using Linked Employer-Employee Data.” Economica, 73, 99-127.

Dale-Olsen, H. (2013a), "Sickness absence, sick leave pay and pay schemes," LABOUR, 28, 40-63..

Dale-Olsen, H. (2013b). "Absenteeism, efficiency wages, and marginal taxes." Scandinavian Journal of Economics, 115, 1185 - 85 (DOI: 10.1111/sjoe.12028).

Esping-Andersen, G. (1990), The Three Worlds of Welfare Capitalsm. Princeton, NJ: Princeton University Press. Frick, B. and M.A. Malo (2008), "Labor Market Institutions and Individual Absenteeism in the European Union: The Relative Importance of Sickness Benefit Systems and Employment Protection Legislation", Industrial Relations, 47, 505 - 529.

Gimeno, D., F. G. Benavides, B. C. Amick, J. Benach, and J. M. Martínez. (2004). "Psychosocial factors and work related sickness absence among permanent and non-permanent employees", Journal of Epidemiology and Community Health, 58, 870-76. 
Gneezy, U., K. L. Leonard, and J. A. List (2009), "Gender Differences in Competition: Evidence from a Matrilineal and a Patriarchal Society", Econometrica, 77, 637-1664.

Goetzel, R. Z., Long, S.R., Ozminkowski, R. J., Hawkins, K., Wang, S. and Lynch, W. (2004), "Health, Absence, Disability, and Presenteeism Cost Estimates of Certain Physical and Mental Health Conditions Affecting U. S. Employers,” Journal of Occupational and Environmental Medicine, 46: 398 412.

Gronberg, T. J. and W. R. Reed (1994), “Estimating Workers' Marginal Willingness to Pay for Job Attributes Using Duration Data," The Journal of Human Resources, 29, 911 - 931.

Grossman, M. (1972), “On the Concept of Health Capital and the Demand for Health,” The Journal of Political Economy, 80, 223 - 255.

Hahn, J., Todd, P. and van der Klaauw, W. (2001), "Identification and Estimation of Treatment Effects with a Regression-Discontinuity Design," Econometrica, 69, 201 - 209.

Haley, H. R. (2003), The response of worker effort to piece Rates. Evidence from the Midwest Logging Industry," Journal of Human Resources, 38, 225 - 49.

Hassink, W. and Koning, P.(2009), "Do Financial Bonuses Reduce Employee Absenteesim? Evidence from a Lottery," Industrial \& Labor Relations Review, 62, 327 - 342.

Hemp, P. (2004), "Presenteeism - At work, but out of it," Harvard Business Review, October 2004, 1 - 9.

Henrekson, M. and Persson, M. (2004), "The Effects on Sick Leave of Changes in the Sickness Insurance System", Journal of Labor Economics, 22, 87 - 113.

Heywood, J.S. and Jirjahn, U. (2004). "Teams, Teamwork and Absence." Scandinavian Journal of Economics, 106: $765-782$.

Holmøy, A. (2013), Arbeids- og bedriftsundersokelsen 2012. Dokumentasjonsrapport. Notater 38/2013. Oslo og Kongsvinger: Statistisk sentralbyrå.

Hwang, H., D.T Mortensen, and W. R. Reed (1998), “Hedonic Wages and Labor Market Search,” Journal of Labor Economics, 16, 815-847

Johansson, P. and M. Palme (1996), "Do Economic Incentives AffectWorker Absence? Empirical Evidence

Using Swedish Data", Journal of Public Economics, 59, 195-218.

Johansson, P. and Palme, M. (2002), “Assessing the Effect of Public Policy on Worker Absenteeism,” Journal of Human Resources, 37, 381 - 409.

Labour Research Department (2015), Sickness absence and sick pay - a guide for trade union reps. LRD Booklets June 2015.

Nielsen, H. S., T. Sørensen, and C. R. Taber (2010), "Estimating the Effects of Aid on College Enrollment: Evidence from a Government Grant Policy Reform," American Economic Journal: Economic Policy, 2, 185 $-215$.

OECD (2010), Sickness, Disability and Work: Breaking the Barriers. A synthesis of findings across OECD countries. Paris: OECD. 
Pichler, S. and N. R. Ziebarth (2016), The Pros and Cons of Sick Pay Schemes: A Method to Test for Contagious Presenteeism and Shirking Behavior. IZA DP No. 8850.

Salop, S. C. (1979), "A Model of the Natural Rate of Unemployment," American Economic Review, 69, $117-125$.

Skatun, J.D. (2003), “Take some days off, why don't you? - Endogenous sick leave and pay,” Journal of Health Economics, 22, 379 - 402.

Treble, J. and T. Barmby (2011), Worker Absenteeism and Sick Pay. Cambridge, UK: Cambridge University Press. van Wanrooy, B., H. Bewley, A. Bryson, J. Forth, S. Freeth, L. Stokes and S. Wood (2013), Employment Relations in the Shadow of Recession. Findings from the 2011 Workplace Employment Relations Study. London: Palgrave Macmillan.

Wahlström, R. and Alexanderson, K. (2004), “Chapter 11. Physicians' sick-listing practices”, Scandinavian Journal of Public Health, Vol. 32 (63 Supplement), 222-255.

Ziebarth, N. R. and Karlsson, M. (2010), “A natural experiment on sick pay cuts, sickness absence, and labor costs," Journal of Public Economics, 94, 1108 - 1122.

Ziebarth, N. R. and Karlsson, M. (2013), “The effects of expanding the generosity of the statutory sickness insurance system," Journal of Applied Econometrics, 29, 208 - 230.

Ziebarth, N. R. (2013), "Long-Term Absenteeism and Moral Hazard - Evidence from a Natural Experiment", Labour Economics, 24, 277 - 292. 
Table 1 The private sector sick leave rate and sick pay regimes. Britain 2011 and Norway 2012.

\begin{tabular}{|c|c|c|c|c|c|c|}
\hline & \multicolumn{3}{|c|}{ Britain } & \multicolumn{3}{|c|}{ Norway } \\
\hline & All & $\begin{array}{l}\text { Public } \\
\text { sick pay } \\
\text { only }\end{array}$ & $\begin{array}{l}\text { Additional } \\
\text { private } \\
\text { sick pay }\end{array}$ & All & $\begin{array}{l}\text { Public } \\
\text { sick pay } \\
\text { only }\end{array}$ & $\begin{array}{l}\text { Additional } \\
\text { private } \\
\text { sick pay }\end{array}$ \\
\hline Sick leave rate & 0.044 & 0.045 & 0.042 & 0.068 & 0.069 & 0.066 \\
\hline Sick leave rate-adjusted & - & - & - & 0.055 & 0.057 & 0.053 \\
\hline Ln hourly wage & 2.199 & 2.053 & 2.353 & 3.110 & 2.957 & 3.220 \\
\hline Over 6G in earnings & 0.369 & 0.358 & 0.386 & 0.299 & 0.178 & 0.449 \\
\hline Private sick pay & 0.484 & 0 & 1 & 0.477 & 0 & 1 \\
\hline Extended leave & 0.480 & 0.256 & 0.720 & 0.189 & 0.182 & 0.405 \\
\hline Private health insurance/GP & 0.156 & 0.095 & 0.220 & 0.190 & 0.233 & 0.341 \\
\hline Risky work & 0.342 & 0.382 & 0.299 & 0.262 & 0.337 & 0.226 \\
\hline Work control index & 1.751 & 1.680 & 1.841 & 1.585 & 1.574 & 1.598 \\
\hline (Design, discretion, pace) & & & & & & \\
\hline $\begin{array}{l}\text { Short time before new recruits } \\
\text { perform as well as more } \\
\text { experienced workers }\end{array}$ & 0.321 & 0.385 & 0.253 & 0.387 & 0.456 & 0.269 \\
\hline Log workforce size & 2.683 & 2.486 & 2.893 & 2.948 & 2.783 & 3.089 \\
\hline High worker turnover & 0.571 & 0.593 & 0.544 & 0.498 & 0.540 & 0.453 \\
\hline Trade union agreement(s) & 0.172 & 0.063 & 0.289 & 0.793 & 0.688 & 0.711 \\
\hline High powered incentive index & 0.671 & 0.511 & 0.876 & 0.739 & 0.667 & 0.845 \\
\hline
\end{tabular}

Note: Population: 2680(1858) WERS2011- and 1888 (1107) NWERS2012-workplaces (private sector workplaces in parentheses). All observations are weighted to be representative for the population of workplaces with at least 10 employees. 
Table 2 Pay and benefit schemes, working conditions, and statutory pay in Britain and Norway.

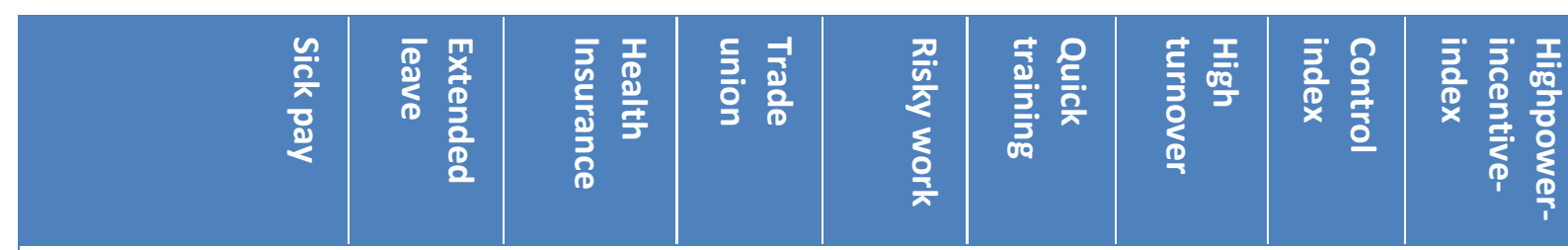

\section{A) Basic}

\begin{tabular}{|lccccccccc|}
\hline Intercept & $0.427^{* *}$ & $0.439^{* *}$ & $0.159^{* *}$ & $0.077^{* *}$ & $0.334^{* *}$ & $0.334^{* *}$ & $0.584^{* *}$ & $1.785^{* *}$ & $0.658^{* *}$ \\
\hline Norway & $(0.033)$ & $(0.034)$ & $(0.022)$ & $(0.012)$ & $(0.043)$ & $(0.033)$ & $(0.031)$ & $(0.040)$ & $(0.061)$ \\
\hline & -0.045 & $-0.231^{* *}$ & 0.067 & $0.686^{* *}$ & -0.042 & 0.117 & -0.033 & $-0.262^{* *}$ & -0.090 \\
\hline $\begin{array}{l}\text { > 6G in } \\
\text { earnings }\end{array}$ & $(0.042)$ & $(0.037)$ & $(0.034)$ & $(0.039)$ & $(0.037)$ & $(0.063)$ & $(0.060)$ & $(0.067)$ & $(0.069)$ \\
\hline $\begin{array}{l}\text { NorwayX> } \\
\text { 6G in } \\
\text { earnings }\end{array}$ & $0.151^{*}$ & $0.140^{*}$ & $0.231^{*}$ & 0.041 & -0.067 & $-0.118^{*}$ & 0.063 & 0.081 & $0.396^{*}$ \\
\cline { 2 - 10 }$y$ & $(0.070)$ & $(0.109)$ & $(0.044)$ & $(0.085)$ & $(0.055)$ & $(0.074)$ & $(0.126)$ & $(0.185)$ \\
\hline R2 & $0.074)$ & $(0.087)$ & $(0.074)$ & $(0.074)$ & $(0.082)$ & $(0.032)$ & $(0.031)$ & $(0.148)$ & $(0.062)$ \\
\hline
\end{tabular}

B) Within industry (2-digit SIC controls)

\begin{tabular}{|c|c|c|c|c|c|c|c|c|c|}
\hline Intercept & $0.453^{* *}$ & $0.440^{* *}$ & $0.203^{* *}$ & $0.109^{*}$ & $0.378^{* *}$ & $0.291^{* *}$ & $0.554^{* *}$ & $1.774^{* *}$ & $0.685^{* *}$ \\
\hline & $(0.035)$ & $(0.034)$ & $(0.030)$ & $(0.048)$ & $(0.030)$ & $(0.053)$ & $(0.048)$ & $(0.083)$ & $(0.073)$ \\
\hline \multirow[t]{2}{*}{ Norway } & -0.053 & $-0.211^{* *}$ & 0.055 & $0.614^{* *}$ & $-0.083^{*}$ & $0.115^{*}$ & -0.038 & -0.167 & 0.011 \\
\hline & $(0.036)$ & $(0.041)$ & $(0.034)$ & $(0.053)$ & $(0.031)$ & $(0.058)$ & $(0.051)$ & $(0.086)$ & $(0.080)$ \\
\hline \multirow{2}{*}{$\begin{array}{l}>6 G \text { in } \\
\text { earnings }\end{array}$} & 0.118 & 0.112 & 0.153 & $0.191^{* *}$ & -0.021 & 0.001 & 0.067 & 0.168 & 0.080 \\
\hline & (0.077) & $(0.078)$ & (0.087) & $(0.070)$ & $(0.072)$ & (0.094) & (0.131) & (0.143) & $(0.183)$ \\
\hline \multirow{3}{*}{$\begin{array}{l}\text { NorwayX> } \\
6 \mathrm{G} \text { in } \\
\text { earnings }\end{array}$} & $0.157^{*}$ & 0.081 & -0.077 & $-0.271^{* *}$ & -0.037 & -0.127 & -0.155 & 0.116 & 0.078 \\
\hline & $(0.072)$ & $(0.106)$ & $(0.085)$ & $(0.087)$ & $(0.030)$ & $(0.106)$ & $(0.135)$ & $(0.153)$ & $(0.073)$ \\
\hline & & & & & & & & & \\
\hline R2 & 0.222 & 0.187 & 0.117 & 0.235 & 0.258 & 0.202 & 0.234 & 0.210 & 0.271 \\
\hline
\end{tabular}

Note: Population: WERS 2011- and NWERS 2012-workplaces. 2317 observations. Linear probability model or linear regressions. Dependent variable: dummy variable or index (last two columns) associated with the variable given by the column head. The reference is expressed by Britain and earnings $<=6 \mathrm{G}$. All observations are weighted to be representative for the population of workplaces with at least 10 employees. The industry control vector in Panel B) takes into account 2-digit SIC industry differentials. Industry clustered standard errors presented in parentheses. ${ }^{*}$ and ${ }^{* *}$ denote 5 and 1 percent level of significance, respectively. 
Table 3 Coordinated pay and benefit schemes and working conditions. Spearman correlations.

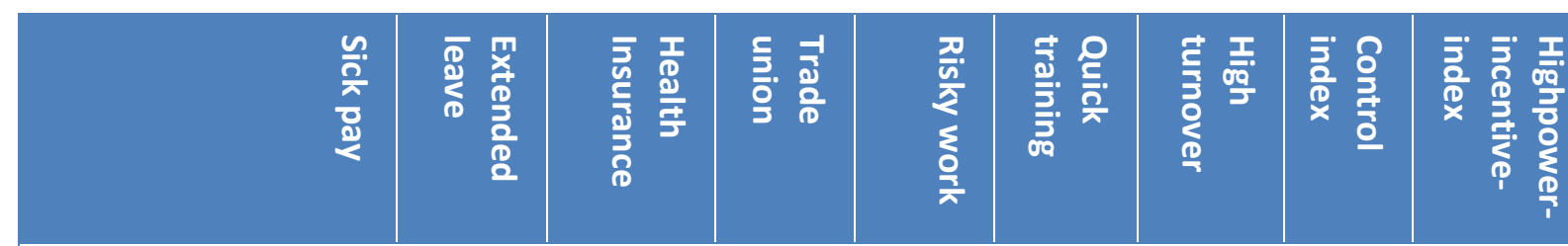

\section{A) Britain}

\begin{tabular}{|c|c|c|c|c|c|c|c|c|c|}
\hline Ext.leave & $0.52^{* *}$ & & & & & & & & \\
\hline Health ins. & $0.22^{* *}$ & $0.16^{* *}$ & & & & & & & \\
\hline T. union & $0.36^{* *}$ & $0.33^{* *}$ & -0.02 & & & & & & \\
\hline Risky work & $-0.07^{*}$ & -0.05 & $-0.15^{* *}$ & $0.12^{* *}$ & & & & & \\
\hline Quick train. & $-0.17^{* *}$ & $-0.18^{* *}$ & $-0.10^{* *}$ & -0.05 & $0.06^{*}$ & & & & \\
\hline High turn. & -0.05 & $-0.07^{*}$ & 0.05 & $-0.12^{* *}$ & -0.05 & 0.02 & & & \\
\hline Control index & $0.06^{*}$ & 0.04 & $0.13^{* *}$ & $-0.06^{*}$ & $-0.10^{* *}$ & $-0.09^{* *}$ & 0.03 & & \\
\hline HP.incentives & $0.24^{* *}$ & $0.30^{* *}$ & $0.29^{* *}$ & $0.19^{* *}$ & $-0.08^{* *}$ & $-0.10^{* *}$ & 0.04 & 0.01 & \\
\hline Over 6G & $0.14^{* *}$ & $0.10^{* *}$ & $0.17^{* *}$ & $0.07^{*}$ & $-0.06^{*}$ & $-0.05^{* *}$ & 0.01 & -0.01 & $0.14^{* *}$ \\
\hline
\end{tabular}

\section{B) Norway}

\begin{tabular}{|lccccccccc|}
\hline Ext.leave & $0.30^{* *}$ & & & & & & & & \\
\hline Health ins. & $0.15^{* *}$ & $0.15^{* *}$ & & & & & & & \\
\hline T. union & 0.02 & $-0.08^{* *}$ & -0.06 & & & & & & \\
\hline Risky work & $-0.10^{* *}$ & -0.03 & 0.01 & $0.13^{* *}$ & & & & & \\
\hline Quick train. & $-0.23^{* *}$ & $-0.16^{* *}$ & $-0.07^{*}$ & $0.10^{* *}$ & 0.03 & & & & \\
\hline High turn. & $-0.16^{* *}$ & $-0.13^{* *}$ & -0.04 & -0.03 & $-0.08^{*}$ & $0.22^{* *}$ & & & \\
\hline Control index & 0.04 & $0.08^{* *}$ & -0.01 & $-0.20^{* *}$ & $-0.11^{* *}$ & $-0.16^{* *}$ & -0.03 & & \\
\hline HP.incentives & $0.20^{* *}$ & $0.24^{* *}$ & $0.19^{* *}$ & $-0.21^{* *}$ & -0.05 & $-0.20^{* *}$ & -0.06 & $0.15^{* *}$ & \\
\hline Over 6G & $0.38^{* *}$ & $0.30^{* *}$ & $0.19^{* *}$ & $-0.15^{* *}$ & -0.05 & $-0.30^{* *}$ & $-0.22^{* *}$ & $0.12^{* *}$ & $0.38^{* *}$ \\
\hline & & & & & & & & & \\
\hline
\end{tabular}

Note: Population: WERS 2011- and NWERS 2012-workplaces. All observations are weighted to be representative for the population of workplaces with at least 10 employees. ${ }^{x},{ }^{*}$, and ${ }^{* *}$ denote 10,5 , and 1 percent level of significance, respectively. 
Table 4 The relationship between pay, sick pay and absenteeism in Britain and Norway.

\begin{tabular}{|c|c|c|c|c|c|c|c|}
\hline & \multicolumn{4}{|c|}{ Observed sick leave rate } & \multicolumn{3}{|c|}{$\begin{array}{c}\text { Sick leave rate } \\
\text { adjusted }\end{array}$} \\
\hline & Model 0 & Model 1 & Model 2 & Model 3 & Model 4 & Model 5 & Model 6 \\
\hline \multicolumn{8}{|c|}{ A) Parameter estimates } \\
\hline \multirow[t]{2}{*}{$\operatorname{Norway}(\mathrm{N})$} & $0.903^{* *}$ & -0.046 & 0.090 & -0.601 & -1.468 & -0.425 & -1.874 \\
\hline & $(0.073)$ & $(0.477)$ & $(0.554)$ & $(0.888)$ & $(1.013)$ & $(0.657)$ & $(1.201)$ \\
\hline \multirow[t]{2}{*}{ Lnw } & & $-0.605^{* *}$ & $-0.642^{* *}$ & $-0.685^{* *}$ & $-1.485^{* *}$ & $-0.668^{* *}$ & $-1.403^{* *}$ \\
\hline & & $(0.158)$ & $(0.159)$ & $(0.236)$ & $(0.390)$ & $(0.160)$ & $(0.411)$ \\
\hline \multirow[t]{2}{*}{ Lnw $>$ G6 } & & 0.170 & 0.146 & 0.141 & 0.225 & 0.138 & 0.189 \\
\hline & & $(0.106)$ & $(0.122)$ & $(0.132)$ & $(0.180)$ & $(0.118)$ & $(0.172)$ \\
\hline \multirow[t]{2}{*}{ NorXLnw } & & $0.514^{* *}$ & $0.461^{*}$ & 0.482 & $1.228^{* *}$ & $0.542^{*}$ & $1.234^{*}$ \\
\hline & & $(0.199)$ & $(0.227)$ & $(0.295)$ & $(0.445)$ & $(0.256)$ & $(0.522)$ \\
\hline \multirow[t]{2}{*}{ NorXLnw>G6 } & & $-0.263^{* *}$ & $-0.233^{x}$ & $-0.236^{x}$ & -0.295 & $-0.238^{x}$ & -0.275 \\
\hline & & $(0.113)$ & (0.129) & $(0.143)$ & $(0.181)$ & $(0.124)$ & (0.177) \\
\hline \multicolumn{8}{|c|}{ B) Estimated linear expressions } \\
\hline \multirow{2}{*}{$\begin{array}{l}\text { Britain:Lnw } \\
<\text { G6 }\end{array}$} & & $-0.605^{* *}$ & $-0.642^{* *}$ & $-0.688^{* *}$ & $-1.485^{* *}$ & $-0.668^{* *}$ & $-1.403^{* *}$ \\
\hline & & $(0.158)$ & (0.159) & $(0.236)$ & $(0.390)$ & $(0.160)$ & $(0.411)$ \\
\hline \multirow{2}{*}{$\begin{array}{l}\text { Britain: } \\
\text { Lnw>G6 }\end{array}$} & & $-0.435^{* *}$ & $-0.496^{* *}$ & $-0.545^{*}$ & $-1.259^{* *}$ & $-0.530^{* *}$ & $-1.214^{* *}$ \\
\hline & & $(0.160)$ & $(0.176)$ & $(0.241)$ & $(0.334)$ & $(0.167)$ & $(0.343)$ \\
\hline \multirow[t]{2}{*}{$\mathrm{N}:$ Lnw $<\mathrm{G} 6$} & & -0.091 & -0.181 & $-0.204^{x}$ & $-0.257^{*}$ & -0.127 & -0.169 \\
\hline & & $(0.082)$ & $(0.112)$ & $(0.120)$ & $(0.111)$ & $(0.172)$ & (0.209) \\
\hline \multirow[t]{2}{*}{$\mathrm{N}: \operatorname{Lnw}>\mathrm{G} 6$} & & $-0.184^{* *}$ & $-0.268^{* *}$ & $-0.300^{* *}$ & $-0.552^{* *}$ & $-0.364^{*}$ & $-0.444^{*}$ \\
\hline & & $(0.070)$ & $(0.098)$ & $(0.101)$ & $(0.189)$ & $(0.184)$ & $(0.225)$ \\
\hline \multicolumn{8}{|l|}{ Controls: } \\
\hline Basic & & & Yes & Yes & Yes & & Yes \\
\hline Industry & & & Yes & Yes & Yes & & Yes \\
\hline Workforce & & & & Yes & & & \\
\hline Selection & No & No & No & No & $\begin{array}{l}\text { No private } \\
\text { sick pay }\end{array}$ & No & $\begin{array}{l}\text { No private } \\
\text { sick pay }\end{array}$ \\
\hline $\mathrm{R} 2$ & 0.058 & 0.057 & 0.075 & 0.075 & 0.117 & 0.070 & 0.110 \\
\hline Observations & 2150 & 2150 & 2082 & 2082 & 785 & 2082 & 785 \\
\hline
\end{tabular}

Note: Population: WERS2011- and NWERS2012-workplaces. All observations are weighted to be representative for the population of workplaces with at least 10 employees. OLS regressions. Dependent variable: $\ln (a /(1-a))(=$ the logit of the sick leave rate). Lnw expresses log hourly wage measured in pounds. Lnw>G6 expresses Inw*I(earnings $>6 G)$, i.e., the interaction between log hourly wage and the dummy for whether earnings are above $6 \mathrm{G}$ (the earnings threshold for public sick pay in Norway). "NorX" then expresses the interaction with the Norway dummy. Note that by multiplying the estimated linear expressions by (1-a) one estimates the elasticity of sick leave rate w.r.t. the hourly wage. Basic control vector: dummy for trade union agreement, working conditions such as risk (1), pollution (1), and physical (1), pay regimes (4), benefits (3), worker discretion and design (2), team (1) and recruitment costs (1). The industry control vector takes into account 2-digit SIC industry differentials. The workforce control vector takes into account log workforce size, ratio of fulltime workers and country-specific rate of 8 main occupational groups (basically 1-digit ISCO occupational code, reference=management and professionals) ${ }^{x}, *$, and $^{* *}$ denote 10,5 , and 1 percent level of significance, respectively. 
Table 5 The relationship between pay, sick pay and absenteeism in Britain and Norway.

Estimated elasticities of the sickness leave rate w.r.t. the hourly wage

\begin{tabular}{|c|c|c|c|c|}
\hline & \multicolumn{2}{|c|}{ At country-mean } & \multicolumn{2}{|c|}{ At country-specific group mear } \\
\hline & Britain & Norway & Britain & Norway \\
\hline Lnw $<6 G$ & $-0.611^{* *}$ & -0.169 & $-0.609^{* *}$ & -0.168 \\
\hline Lnw>6G & $-0.472^{* *}$ & $-0.250^{* *}$ & $-0.474^{* *}$ & $-0.254^{* *}$ \\
\hline
\end{tabular}

Note: Population: WERS2011- and NWERS2012-workplaces. Predicted elasticities of the sickness absence rate w.r.t. the hourly wage. The log hourly wage is measured in pounds. All predictions are representative for the population of workplaces with at least 10 employees. The predictions are calculated based on the estimates of the OLS regression presented in Table 4, Model 2. Lnw>G6 and Lnw<G6 express log hourly wages for those with earnings above and below $6 \mathrm{G}$ (the earnings threshold for public sick pay in Norway). ${ }^{*},{ }^{*}$, and ${ }^{* *}$ denote 10,5 , and 1 percent level of significance, respectively. 
Table A1 Descriptive statistics on wages, sick leaves and other characteristics

\begin{tabular}{|c|c|c|c|c|}
\hline & \multicolumn{2}{|c|}{ Britain } & \multicolumn{2}{|c|}{ Norway } \\
\hline & Mean & Std. & Mean & Std \\
\hline Sick leave rate & 0.045 & 0.086 & 0.055 & 0.046 \\
\hline Sick leave rate, $<6 G$ & 0.046 & 0.090 & 0.059 & 0.041 \\
\hline Sick leave rate, $>6 G$ & 0.044 & 0.090 & 0.044 & 0.054 \\
\hline Logit (sr) & -4.255 & 2.139 & -2.848 & 0.773 \\
\hline Ln hourly wage & 2.177 & 0.477 & 3.079 & 0.444 \\
\hline Private sick pay & 0.453 & 0.498 & 0.450 & 0.500 \\
\hline Extended leave & 0.459 & 0.500 & 0.284 & 0.451 \\
\hline Private health insurance & 0.181 & 0.385 & 0.278 & 0.448 \\
\hline Log workforce size & 2.635 & 0.905 & 2.940 & 0.881 \\
\hline Risky work & 0.325 & 0.469 & 0.278 & 0.448 \\
\hline Work control index & 1.804 & 0.678 & 1.593 & 0.908 \\
\hline Break & 0.327 & 0.469 & 0.487 & 0.500 \\
\hline Discretion & 0.750 & 0.433 & 0.428 & 0.495 \\
\hline Autonomy & 0.726 & 0.446 & 0.428 & 0.495 \\
\hline Short-training time & 0.312 & 0.463 & 0.370 & 0.483 \\
\hline High worker turnover & 0.581 & 0.494 & 0.494 & 0.500 \\
\hline Trade union agreement(s) & 0.084 & 0.277 & 0.699 & 0.458 \\
\hline High powered incentive index & 0.677 & 0.873 & 0.739 & 0.841 \\
\hline Performance pay & 0.321 & 0.467 & 0.363 & 0.481 \\
\hline Merit pay & 0.227 & 0.419 & 0.281 & 0.450 \\
\hline ESS & 0.064 & 0.250 & 0.063 & 0.243 \\
\hline ESOP & 0.065 & 0.247 & 0.031 & 0.174 \\
\hline Export & 0.124 & 0.330 & 0.104 & 0.305 \\
\hline Ratio of fulltime workers to all & 0.176 & 0.136 & 0.802 & 0.239 \\
\hline $\mathbf{N}$ & & & & \\
\hline
\end{tabular}

Note: Populations: private sector WERS2011(Britain) - and NWERS2012(Norway)-workplaces. Log hourly pay for Britain and Norway is based on 2011 pounds (PPP-adjusted), where $1 f=9.032$ Norwegian krones (NOK)). The workplace sick leave rate is measured as the absence rate (for both self-declared and physician-certified sickness absence) the last year (prior to interview). logit (sr) denotes $\ln (\mathrm{sr} /(1-\mathrm{sr}))$. 
Figure 1 The public sick pay in Britain and Norway. Monthly figures.

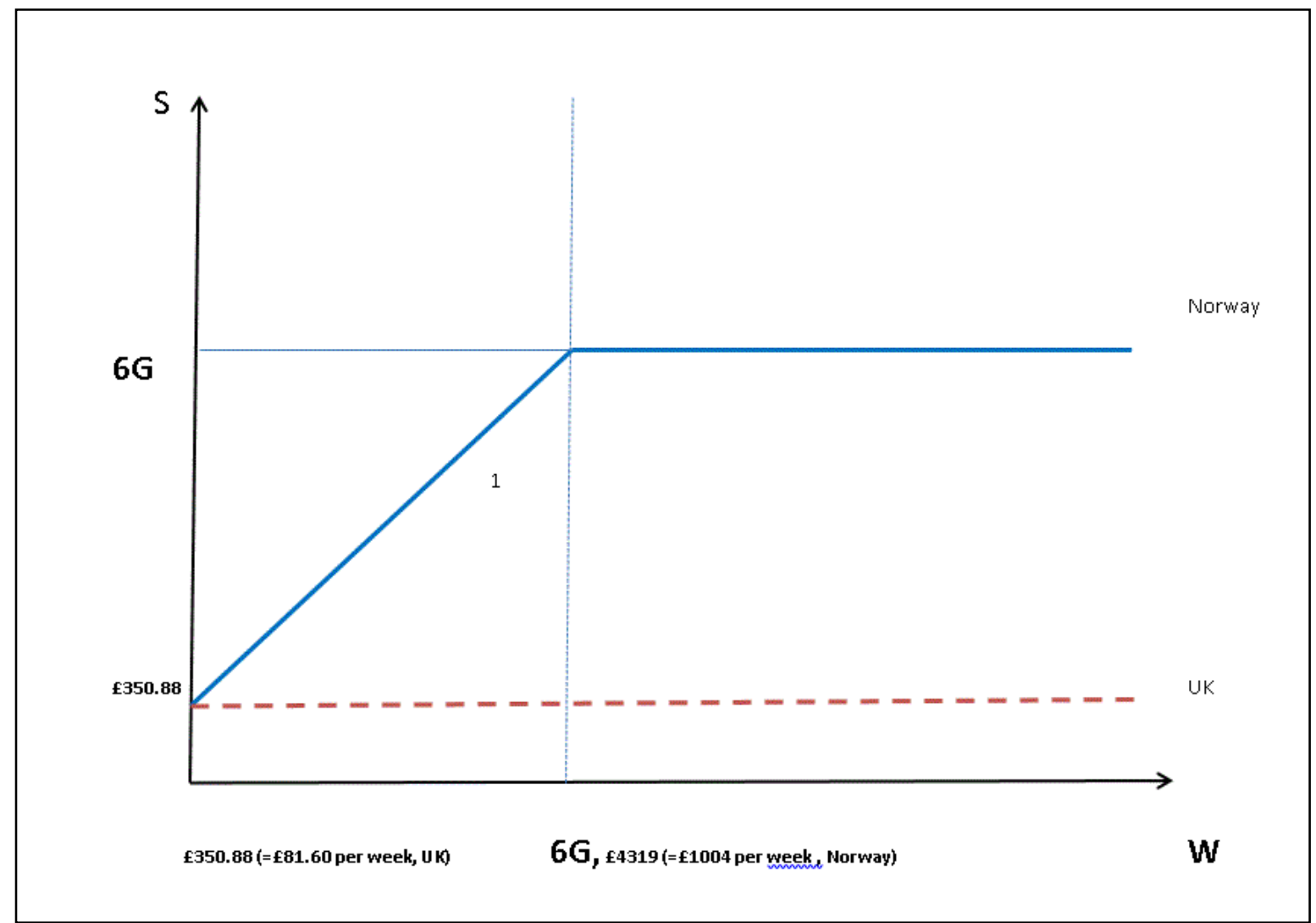

Note: The figure is based on 2011-legislation. All money values are based on 2011 pounds (PPP-adjusted), where $1 \mathrm{f}=9.032$ Norwegian krones (NOK)). We present monthly figures, since UK-legislation is limited to a maximum of 28 weeks. In Norway the annual 6G-threshold is $f 51828$. 
Figure 2 Distribution of the sick leave rate. 2011/2012. Kernel densities. Britain and Norway

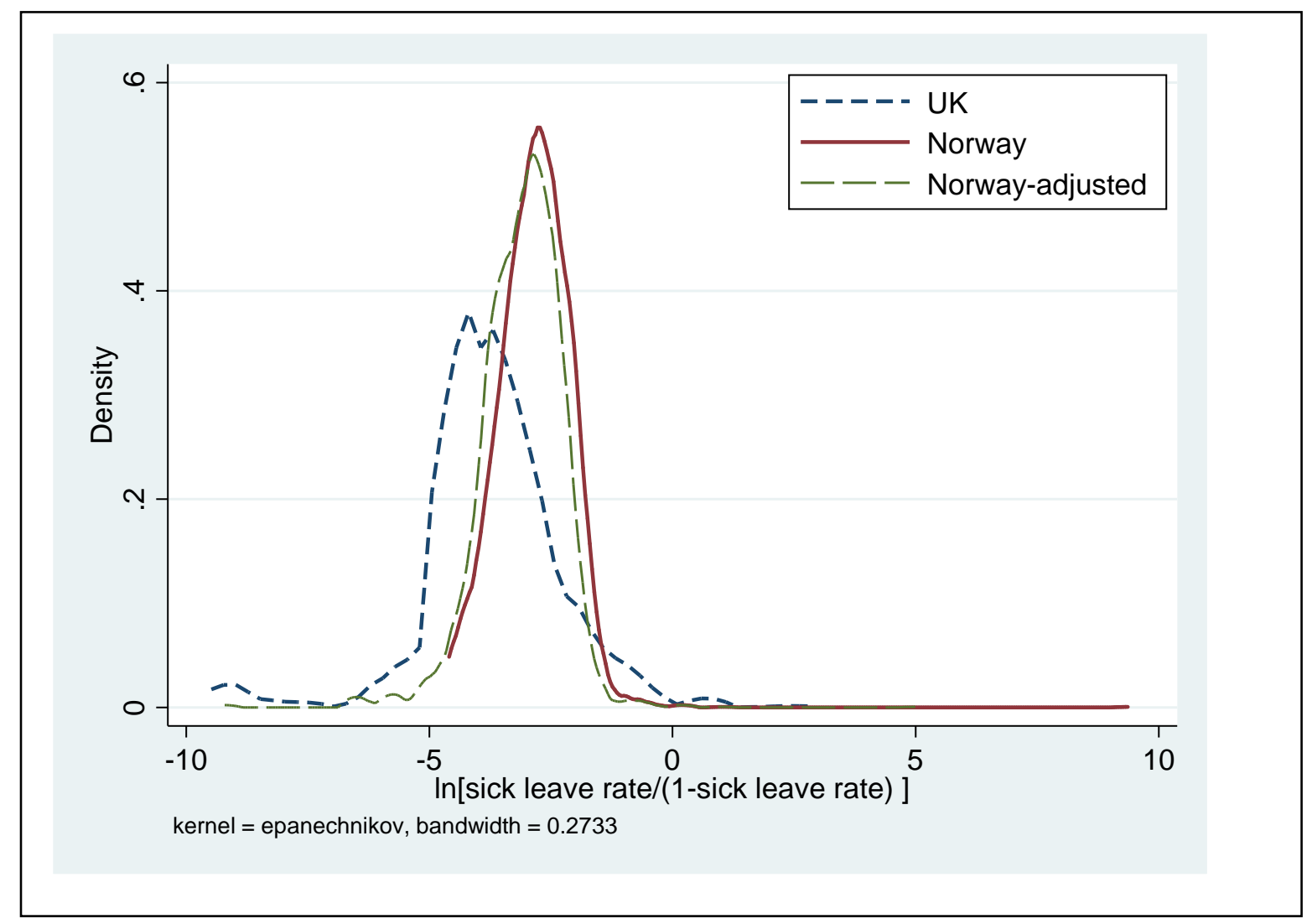

Note: The sick leave rate is measured by: $\ln (s r /(1-s r))(=$ the logit of the sick leave rate). The adjusted sick leave rate take into account graded sick leaves, i.e., when workers are partly on sick leave (for example, 50\%). 
Figure 3 Country-differences. Selected marginal effects. Reference: BRITAIN and earnings<6G.

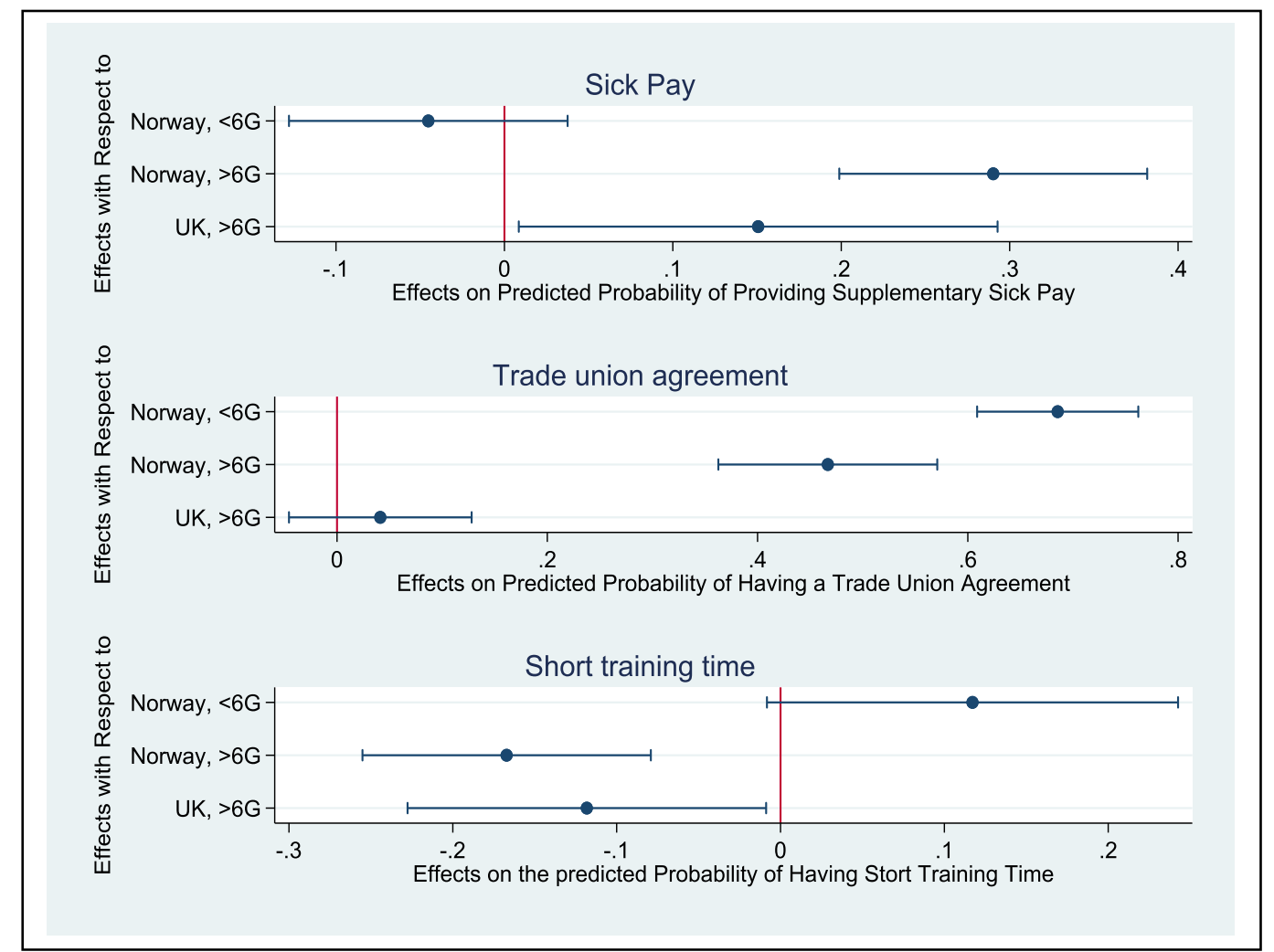

Note: Selected marginal effects estimated from Table 2, Panel A). 
Figure 4 Country-differences. Predicted probabilities within 2-digit industry.

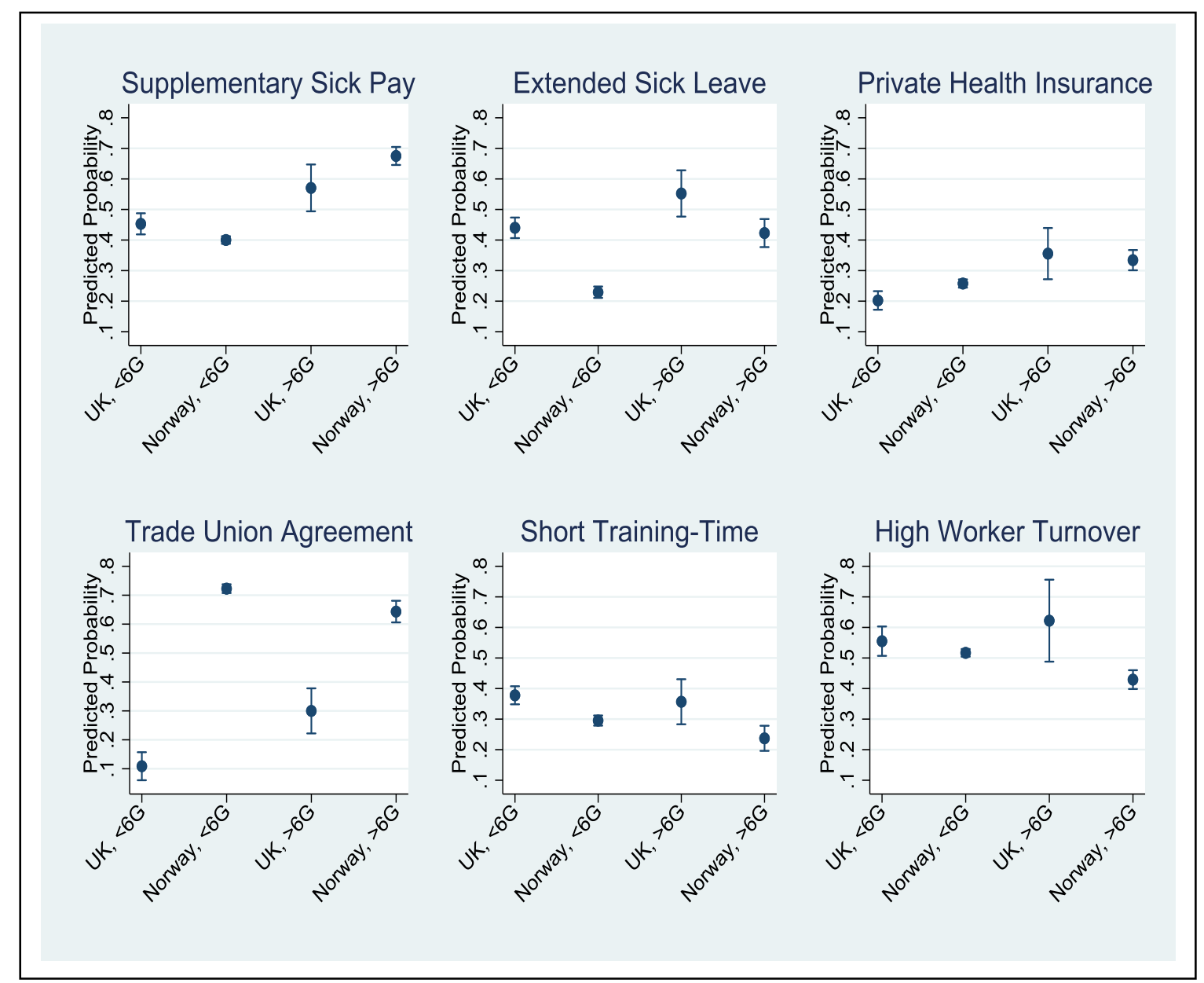

Note: Predicted average effects estimated from Table 2, Panel B), where we control for 2-digit industry differentials. 